\title{
EFFICIENCY OF SOME WEED CONTROL TREATMENTS ON GROWTH, YIELD AND ITS ATTRIBUTES OF MAIZE (Zea mays, L.) PLANTS AND ASSOCIATED WEEDS. \\ Ahmed, S. A.*; H. M. Shams ${ }^{\star \star}$; I. M. El-Metwally*; M. N. Shehata** and Mona A. El-Wakeel* \\ * Botany Department, National Research Centre, Dokki, Cairo, Egypt. \\ ${ }^{* *}$ Botany Department, Faculty of Science, Benha University, Egypt.
}

\begin{abstract}
Two field experiments were conducted at the Experimental Station of the National Research Centre at Shalakan, Kalyoubia Governorate, Egypt, to study the influence of some weed control treatments i.e. Fluroxypyr $(0.2 \mathrm{~L} / \mathrm{fed})$, Isoproturon $(1.0 \mathrm{~L} \mathrm{/} \mathrm{fed),} \mathrm{Metribuzin} \mathrm{(300} \mathrm{gm} \mathrm{/} \mathrm{fed),} \mathrm{Tribenuron-} \mathrm{methyl} \mathrm{(8} \mathrm{gm} \mathrm{/} \mathrm{fed),} \mathrm{Metosulam}$ (0.03 L / fed), Bentazon ( $0.75 \mathrm{~L} / \mathrm{fed})$, Oxadiargyl $(250 \mathrm{gm} / \mathrm{fed})$, two hand hoeing and unweeded as check treatment on growth, yield, yield attributes, chemical composition of maize grains and study the response of associated weeds during the two successive seasons of 2006 and 2007. The main findings could be summarized as follows:

Weed control treatments had a significant effect on number, fresh and dry weight of maize weeds after 60 and 80 days from sowing (DFS). Two hand hoeing and Fluroxypyr provided the best treatments in controlling broad leaved weeds. Two hand hoeing, Metribuzin, Oxadiargyl and Fluroxypyr were significantly the best control treatments of grassy and total weeds up to 80 days after maize sowing as compared to other weed control treatments. Plant height, fresh and dry weight of shoot and leaves / plant were statistically increased as a result of controlling weeds. Two hand hoeing recorded the highest values of the previous characters followed by Metribuzin and Fluroxypyr treatments. Whereas, unweeded treatment showed the lowest values for all characters under study.

Two hand hoeing and the herbicidal treatments markedly increased yield and yield attributes, i.e. weight of ears / plant, ear length (in the first season), number of kernels / row and grain yield / fed. Maximum values of the previous characters were recorded from two hand hoeing, Metribuzin, Fluroxypyr and Oxadiargyl treatments. Weed control treatments significantly increased chemical composition of maize grains when compared with unweeded check. The highest values of carbohydrates and protein percentages were obtained from two hand hoeing followed by Metribuzin and Fluroxypyr treatments. Meanwhile, the highest values of oil percentage were recorded by application of Metribuzin followed by Fluroxypyr, Oxadiargyl and two hand hoeing treatments.

It could be summarized that for maximizing maize yield and its quality by two hand hoeing treatment or using Metribuzin as pre - emergence herbicide and / or using Fluroxypyr as post - emergence after 21 DFS under the environmental conditions of the experiment.
\end{abstract}

\section{INTRODUCTION}

Maize (Zea mays, L.) is one of the most important cereal crops not only in Egypt but all over the world. It ranks the third after wheat and rice. In Egypt the cultivated area with maize is limited to meet the increasing demand of human consumption and animal feedings. Thus, a great attention should be paid to raise its productivity per unit area. This can be achieved through planting the high yielder cultivars and improving its agronomic practices. 
Ahmed, S. A. et al.

Weed control play an active role in raising maize grain yield, since weed cause great losses in yield reached to 32.4 to $50 \%$ (Sharma et al., 2000). As hand labor became scarce and costly, herbicides replaced it as a cheap and easy method for weed control in maize fields. In general, application of herbicides depends not only on its efficiency in controlling weeds, but also on its effect on maize plants. In this respect, satisfactory maize weed control results were obtained by hand hoeing (Ahmed, 1999; Abd El - Samie, 2000; Mekky, 2001; Attalla, 2002a and 2002b; Saad El - Din et al., 2004 and El - Metwally et al., 2006), by the application of Fluroxypyr (Abd El - Samie, 2001; El - Metwally et al., 2001; Mekky, 2001; Attalla, 2002b; El - Metwally, 2002; Elgayar, 2004 and Sharara et al, 2005), Isoproturon (Saad El - Din and Ahmed, 2004), Metribuzin (Abd El - Samie, 2000; Senseovic, 2004 and El - Metwally et al., 2006), Tribenuron - methyl (Attalla, 2002a and Saad El - Din and Ahmed, 2004), Metosulam (El Metwally, 2002), Bentazon (Mohamed, 2004 and Sharara et al., 2005) and Oxadiargyl (Konstantinovic and Meseldzija, 2007).

Some researchers have reported increased maize growth, yield and yield attributes where hand hoeing (Ahmed, 1999; Abd El - Samie, 2000; Abd El - Samie, 2001; Mekky, 2001; Mohamed,2004; Sharara et al., 2005 and El - Metwally et al., 2006), Fluroxypyr (Abd El - Samie, 2001; El - Metwally et al., 2001; Mekky, 2001; Elgayar, 2004 and Saad El - Din et al., 2004), Isoproturon (Singh and Singh, 2003), Metribuzin (El - Metwally et al., 2006), Tribenuron - methyl (Attalla, 2002a), Metosulam (El - Metwally, 2002) and Bentazon (El - Metwally et al., 2001; Mohamed, 2004; Saad El - Din et al., 2004 and Kobeasy et al., 2005) applied as weed control treatments.

Chemical composition of maize grains was significantly increased by different weed control treatments. In this respect, (Ahmed, 1999) showed that highest oil and protein percentages in maize grains were obtained with two hand hoeing treatment. Also, (El - Metwally et al., 2001) recorded that protein and oil percentages in maize grains were significantly increased by using different weed control treatments as compared to unweeded treatment. Many other investigators came to the same conclusion (Elgayar, 2004; Mohamed, 2004; Saad El - Din et al., 2004; Kobeasy et al., 2005 and Sharara et al., 2005).

The objective of this investigation is to study the effect of some weed control treatments on growth, yield and yield attributes and associated weeds.

\section{MATERIALS AND METHODS}

Two field experiments were conducted during two successive summer seasons of 2006 and 2007 at Experimental Station of National Research Centre at Shalakan, Kalyoubia Governorate, Egypt. The purpose was to study the influence of some weed control treatments on growth, yield and its attributes of maize as well as the associated weeds. The soil texture was clay loam with medium fertility, containing $1.89 \%$ organic matter and $\mathrm{pH}$ 7.8 . 
The experiments were laid - out in randomized complete blocks design with four replications. The experimental basic unit included 5 ridges, $70 \mathrm{~cm}$ a part and $3.0 \mathrm{~m}$ length, occupying an area of $10.5 \mathrm{~m}^{2}(1 / 400 \mathrm{fed})$. The previous winter crop was faba bean (Vicia faba L.) in both seasons. Maize grains c.v pioneer $30 \mathrm{~K} 8$ sowed in one side of the ridge in hills $25 \mathrm{~cm}$ a part in the second week of May in both seasons. Plants were thinned to one plant per hill (24000 plant / fed) before the first irrigation.

Table 1 presents the common, trade and chemical names as well as rates used / feddan and time of application of applied treatments. The herbicides were applied with knapsack sprayer equipped with one nozzle boom and water volume was $200 \mathrm{~L} /$ fed. The normal cultural practices were kept the same as normally practiced in maize fields except for weed control treatments.

\section{Data recorded:}

1- On Weeds:-

Weeds hand pulled from one quadrate $(1 \times 1 \mathrm{~m})$ from each plot after 60 and 80 DFS and then were identified and separated into three groups, i.e. broad leaved weeds (Portulaca oleracea, L., Corchorus olitorius, L. and Amaranthus hybridus L.) ,grasses (Echinochloa colonum, L. and Cynodon dactylon, L.) and total weeds. Number, fresh and dry weight of weeds (at 70 $\mathrm{C}^{\circ}$ to constant weight) were recorded.

Table 1: Common, trade and chemical names of herbicides as well as rate /fed and time of application of applied treatments.

\begin{tabular}{|c|c|c|c|c|}
\hline $\begin{array}{l}\text { Common } \\
\text { name }\end{array}$ & $\begin{array}{l}\text { Trade } \\
\text { name }\end{array}$ & Chemical name & $\begin{array}{l}\text { Rates / } \\
\text { feddan }\end{array}$ & Time of application \\
\hline Fluroxypyr & $\begin{array}{l}\text { Starane } \\
20 \% \text { EC }\end{array}$ & $\begin{array}{l}\text { [(4-amino- 3, 5- dichloro-6-floro-2- } \\
\text { pyridinyl)oxy] acetic acid. }\end{array}$ & $0.2 \mathrm{~L}$ & $\begin{array}{l}\text { Post - emergence at } 21 \\
{ }^{*} \text { DFS. }\end{array}$ \\
\hline Isoproturon & $\begin{array}{c}\text { Arelon } \\
50 \% \mathrm{FL} \\
\end{array}$ & $\begin{array}{l}\mathrm{N}, \mathrm{N}-\text { dimethyl }-\mathrm{N}-[4-(1- \\
\text { methylethyl)phenyl] urea }\end{array}$ & $1.0 \mathrm{~L}$ & $\begin{array}{l}\text { Post - emergence at } 30 \\
\text { DFS. }\end{array}$ \\
\hline Metribuzin & $\begin{array}{c}\text { Sencor } \\
70 \% \text { WP }\end{array}$ & $\begin{array}{l}\text { (4-amino-6trer-butyl-3-(methyl thio) } \\
1,2 \text {, 4-triazine-5(4H) one). }\end{array}$ & 300 gm & Pre-emergence. \\
\hline $\begin{array}{l}\text { Tribenuron - } \\
\text { methyl }\end{array}$ & $\begin{array}{l}\text { Granstar } \\
75 \% \text { DF }\end{array}$ & $\begin{array}{l}\text { [Methyl 2(((N-(4-methoxy-6-methyl- } \\
\text { 1, 3, 5-triazin-2-Y) methylamine) } \\
\text { carbonyl) amino) sulphul) benzoate]. }\end{array}$ & $8.0 \mathrm{gm}$ & $\begin{array}{c}\text { Post - emergence at } 21 \\
\text { DFS. }\end{array}$ \\
\hline Metosulam & $\begin{array}{c}\text { Sinal } \\
10 \% \text { Sc }\end{array}$ & $\begin{array}{l}\mathrm{N}-(2,6 \text { - dichloro-3-methylphenyl)- } \\
\text { 5,7- dimethoxy-[1, 2, 4] triazolo [1,5- } \\
\text { a] pyrimidine-2-sulphonamide. }\end{array}$ & $0.03 \mathrm{~L}$ & $\begin{array}{c}\text { Post - emergence at } 21 \\
\text { DFS. }\end{array}$ \\
\hline Bentazon & \begin{tabular}{|c|} 
Basagran \\
$48 \%$ AS
\end{tabular} & $\begin{array}{l}\text { (3-isopropyl 1H-2, 1, 3-benza } \\
\text { thiadiazin -4-(3H) one 2, 2-dioxide). }\end{array}$ & $0.75 \mathrm{~L}$ & $\begin{array}{c}\text { Post - emergence at } 21 \\
\text { DFS. }\end{array}$ \\
\hline Oxadiargyl & $\begin{array}{c}\text { Topstar } \\
80 \% \text { WG }\end{array}$ & $\begin{array}{l}\text { 3-[2, 4- dichloro-5-(2-propynyloxy) } \\
\text { phenyl]-5-(1, 1dimethylethyl)-1, 3, 4- } \\
\text { oxadiazol-2(3H)-one]. }\end{array}$ & $250 \mathrm{gm}$ & Pre-emergence. \\
\hline $\begin{array}{l}\text { Two hand } \\
\text { hoeing }\end{array}$ & - & - & - & After 21and 35 DFS \\
\hline unweeded & - & - & - & - \\
\hline
\end{tabular}


Ahmed, S. A. et al.

2-On maize plants:

A- Plant growth:

In both seasons at 60 and 80 DFS, samples of five maize plants were taken randomly from each plot to determine:-

1 - Plant height $(\mathrm{cm})$ 2 - Fresh weight of shoot / plant (gm)

3 - Dry weight of shoot / plant (gm) 4 - Fresh weight of leaves / plant (gm)

5 - Dry weight of leaves / plant (gm)6 - Number of leaves / plant

B- Yield and its attributes:

At harvest, ten plants were taken from each plot to estimate:-

1- Weight of ears / plant (gm). 2- Ear length $(\mathrm{cm})$.

3- Ear diameter (cm).

4- Number of rows/ear.

5- Number of kernels /row.

6- Grain yield (ardab/ fed)

\section{C - Chemical composition of maize grains:-}

C.1 Total protein percent:

The total nitrogen percent of maize grains was estimated using the modified micro - Kjeldahl method as described by Chapman and Pratt (1978). $\mathrm{N}$ - values were multiplied by 6.25 to calculate protein percent.

\section{C.2 Total oil percent:}

Total oil percent in maize grains was determined according to procedure reported in the (A. O. A. C, 1980), using soxhlet equipment.

C.3 Total carbohydrate percent:

Total carbohydrate percentage was determined in maize grains according to Herbert et al. (1971).

\section{Statistical analysis:}

All data were statistically analyzed according to the technique of analysis of variance (ANOVA) as published by Gomez and Gomez (1984). Treatment means were compared at level of $5 \%$ probability.

\section{RESULTS AND DISCUSSION}

\section{1-Growth of weeds:}

The effect of different weed control treatments on number, fresh and dry weight of broad leaved, grasses and total weeds after 60 and 80 days from sowing (DFS) in 2006 and 2007 experiments are presented in Tables 2,3 and 4 .

\section{A- Broad leaved weeds:-}

Number, fresh and dry weight of broad leaved weeds $\left(\mathrm{gm} / \mathrm{m}^{2}\right)$ as affected by different weed control treatments at 60 and 80 DFS in both seasons are recorded in Table 3.

\section{A- 1 - Number of broad leaved weeds $/ \mathrm{m}^{2}$ :}

It is obvious from the results in Table 2 that all weed control treatments revealed significant influences on number of broad leaved weeds at 60 and 80 DFS in both seasons. The results clearly indicate that treatment of two hand hoeing exerted the highest reduction in number of 
broad leaved weeds. Therefore, it decreased number of broad leaved weeds by 96.4 and $95.9 \%$ at 60 DFS as well as 95.4 and $95.7 \%$ at 80 DFS in 2006 and 2007 seasons respectively, as compared to unweeded treatment. With respect to other weed control treatments, the results in Table 2 show that the highest efficiency in decreasing number of broad leaved weeds was obtained from Fluroxypyr followed by Oxadiargyl at 60 DFS in the first season and at 80 DFS in the second season, Oxadiargyl followed by Fluroxypyr at 60 DFS in the second season as well as Fluroxypyr followed by Bentazon treatment at 80 DFS in the first season.

\section{A- 2 - Fresh and dry weight of broad leaved weeds $\left(\mathrm{gm} / \mathrm{m}^{2}\right)$ :}

It is worthy, to notice that the effect of weed control treatments on dry weight of maize weeds followed similar trends to those of fresh weight (Table 2).

The results of weed control treatments presented in Table 2 showed significant effect on fresh and dry weight of broad leaved weeds after 60 and 80 DFS in both seasons. The highest efficiency in decreasing fresh and dry weight of broad leaved weeds was obtained from two hand hoeing, followed by Fluroxypyr, Metribuzin, Oxadiargyl and Bentazon treatments. These results are in general agreement with those recorded by Saad EI - Din et al. (2004), Sharara et al. (2005), El - Metwally et al. (2006) ,Abouziena et al. (2007) and Konstantinovic and Meseldzija (2007).

Table 2: Average of number, fresh and dry weight of broad leaved weeds after 60 and 80 DFS as affected by weed control treatments of 2006 and 2007 growing seasons

\begin{tabular}{|c|c|c|c|c|c|c|c|c|c|c|c|c|}
\hline \multirow{3}{*}{$\begin{array}{l}\text { Characters } \\
\text { Treatments }\end{array}$} & \multicolumn{6}{|c|}{ At 6} & \multicolumn{6}{|c|}{ At } \\
\hline & \multicolumn{2}{|c|}{ Number } & \multicolumn{2}{|c|}{$\begin{array}{c}\text { Fresh weight } \\
\left(\mathrm{gm} / \mathrm{m}^{2}\right)\end{array}$} & \multicolumn{2}{|c|}{$\begin{array}{c}\text { Dry } \\
\text { weight } \\
\left(\mathrm{gm} / \mathrm{m}^{2}\right)\end{array}$} & \multicolumn{2}{|c|}{ Number } & \multicolumn{2}{|c|}{$\begin{array}{c}\text { Fresh weigh } \\
\left(\mathrm{gm} / \mathrm{m}^{2}\right)\end{array}$} & \multicolumn{2}{|c|}{$\begin{array}{c}\text { Dry } \\
\text { weight } \\
\left(\mathrm{gm} / \mathrm{m}^{2}\right)\end{array}$} \\
\hline & 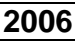 & - & 2006 & 007 & 2006 & & & & & & & \\
\hline Fluroxypyr & 11.8 & & & & 1110 & 8.7 & & & & & & \\
\hline & 8 & & & & 0 & 4 & & & & & 131. & \\
\hline & & & & & & & & & & & & \\
\hline $1-$ & T. & 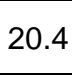 & 5 & & 59.0 & 35.4 & 1 & 160 & & & & \\
\hline & & & & & 3.5 & & & & & & & \\
\hline & & & & & & & & & & & & \\
\hline & & & & & 18.2 & 10.0 & & 6 & & & 5.8 & 27. \\
\hline and & 0.6 & & & & 10.5 & & תח & 10.3 & & & 21 & \\
\hline \multicolumn{13}{|c|}{\begin{tabular}{|c|c|c|c|}
68.9 & 231.5 & 488.4 & 237.1 \\
\end{tabular}} \\
\hline & & & & & & & & & & & 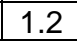 & 1.8 \\
\hline
\end{tabular}

\section{B- Grass weeds:}

Results in (Table 3) clearly showed that the growth of grass was significantly decreased as affected by weed control treatments. Two hand hoeing exerted the highest reduction in number, fresh and dry weight of grass followed by Metribuzin, Oxadiargyl, Fluroxypyr and Isoproturon treatments at 
60 and 80 DFS in both seasons. Similar observations were reported by EI Metwally et al. (2001), Attalla (2002a), El - Metwally (2002), Elgayar (2004), Mohamed (2004), Saad El - Din et al. (2004), El - Metwally et al. (2006) and Abouziena et al. (2007).

Table 3: Average of number, fresh and dry weight of grass after 60 and 80 DFS as affected by weed control treatments of 2006 and 2007 growing seasons.

\begin{tabular}{|c|c|c|c|c|c|c|c|c|c|c|c|c|}
\hline \multirow{3}{*}{ Gharacters } & \multicolumn{6}{|c|}{ At 60 DFS } & \multicolumn{6}{|c|}{ At 80 DFS } \\
\hline & \multicolumn{2}{|c|}{ umber } & \multicolumn{2}{|c|}{$\begin{array}{c}\text { Fresh } \\
\text { weight } \\
\left(\mathrm{gm} / \mathrm{m}^{2}\right)\end{array}$} & \multicolumn{2}{|c|}{$\begin{array}{c}\text { Dry } \\
\text { weight } \\
\left(\mathrm{gm} / \mathrm{m}^{2}\right)\end{array}$} & \multicolumn{2}{|c|}{ Number } & \multicolumn{2}{|c|}{$\begin{array}{c}\text { Fresh weight } \\
\left(\mathrm{gm} / \mathrm{m}^{2}\right)\end{array}$} & \multirow{2}{*}{\multicolumn{2}{|c|}{$\begin{array}{c}\begin{array}{c}\text { Dry } \\
\text { weight } \\
\left.\text { (gm / m }{ }^{2}\right)\end{array} \\
20062007 \\
\end{array}$}} \\
\hline & \multicolumn{2}{|c|}{\begin{tabular}{|l|l|}
2006 & 2007 \\
\end{tabular}} & 2006 & \multirow{2}{*}{2007} & 2006 & 2007 & \multicolumn{2}{|c|}{\begin{tabular}{|l|l|}
2006 & 2007 \\
\end{tabular}} & \multirow{2}{*}{$\frac{2006}{1070.2}$} & 2007 & & \\
\hline Flur & 80.4 & 53 & 587.7 & & 1 & 71.2 & & 5.0 & & & \multicolumn{2}{|c|}{182.1121 .7} \\
\hline & & & & & & & & & & & & \\
\hline & & & & & & & & & & & & \\
\hline & & 70.0 & & & & 94.0 & & & & & & 0 \\
\hline Met & & & 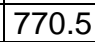 & 53 & & & & & & & & \\
\hline & 6 & & & & & & & & & & & 41 \\
\hline & 9.4 & & 229.1 & & & 19.5 & & 8 & & & 99.0 & 39.4 \\
\hline hand & 4.0 & 2. & 20.1 & & 3.1 & 2.6 & & & & & 6. & \\
\hline & & & & & & & & & & & & \\
\hline & & & & 20.2 & 5. & 1. & & & 7 & & 2.1 & 2.8 \\
\hline
\end{tabular}

\section{C- Total weeds:}

Results relevant showed that number, fresh and dry weight of total weeds was markedly decreased by weed control treatments (Table 4).

In both seasons, the lowest values in number, fresh and dry weight of total weeds after 60 and 80 DFS were obtained by two hand hoeing followed by Metribuzin, Oxadiargyl, Fluroxypyr and Bentazon treatments. The superior treatments decreased dry weight of total weeds at 60 DFS than unweeded treatment by about 97.7, 96.2, 91.0, 81.6 and $75.8 \%$ in the first season, respectively and by $97.6,96.4,92.6,79.8$ and $74.9 \%$ in the second season, respectively. Whereas, the superior treatments decreased the dry weight of total weeds at 80 DFS when compared to unweeded treatment by about 97.1 , $94.7,86.5,80.1$ and $69.3 \%$ in the first season, respectively and by 97.2 , $95.8,90.5,79.9$ and $75.9 \%$ in the second season, respectively.

Generally, results in Tables (2, 3 and 4) indicate that the density of weeds $/ \mathrm{m}^{2}$ in the first season higher than the second season. It's obvious from the recorded results that two hand hoeing and all herbicidal treatments decreased statistically number, fresh and dry weight of broad leaved, grass and total weeds grown with maize as compared with unweeded treatment. These results may be due to the inhibition effect of weed control treatments on weed growth. Two hand hoeing, Metribuzin, Oxadiargyl, Fluroxypyr and Bentazon were the most effective treatments for controlling weeds. The same conclusion was reported by Attalla (2002b), Saad El - Din and Ahmed (2004), El - Metwally et al. (2006) and Konstantinovic and Meseldzija (2007). 
Table 4: Average of number, fresh and dry weight of total weeds after 60 and 80 DFS as affected by weed control treatments of 2006 and 2007 growing seasons.

\begin{tabular}{|c|c|c|c|c|c|c|c|c|c|c|c|c|}
\hline \multirow{3}{*}{ Treatments } & \multicolumn{6}{|c|}{ At 60 DFS } & \multicolumn{6}{|c|}{ At 80 DFS } \\
\hline & \multicolumn{2}{|c|}{ Number } & \multicolumn{2}{|c|}{\begin{tabular}{|l|}
$\begin{array}{c}\text { Fresh weight } \\
\left(\mathrm{gm} / \mathrm{m}^{2}\right)\end{array}$ \\
\end{tabular}} & \multicolumn{2}{|c|}{\begin{tabular}{|c|}
$\begin{array}{c}\text { Dry weight } \\
\left(\mathrm{gm} / \mathrm{m}^{2}\right)\end{array}$ \\
\end{tabular}} & \multicolumn{2}{|c|}{ Number } & \multicolumn{2}{|c|}{\begin{tabular}{|c|}
$\begin{array}{c}\text { Fresh weight } \\
\left(\mathrm{gm} / \mathrm{m}^{2}\right)\end{array}$ \\
\end{tabular}} & \multicolumn{2}{|c|}{$\begin{array}{c}\begin{array}{c}\text { Dry weight } \\
\left(\mathrm{gm} / \mathrm{m}^{2}\right)\end{array} \\
\end{array}$} \\
\hline & 2006 & 2007 & 2006 & 2007 & 2006 & 2007 & 2006 & 2007 & 2006 & 2007 & 2006 & 2007 \\
\hline Fluroxypyr & 92.2 & \begin{tabular}{|l|}
58.7 \\
\end{tabular} & 682.1 & 479.6 & 5.3 & 79.9 & 0.3 & 95.4 & 1282.3 & \begin{tabular}{|l|}
860.8 \\
\end{tabular} & 14.1 & 41.7 \\
\hline Isoproturon & 124.7 & \begin{tabular}{|l|}
71.3 \\
\end{tabular} & 962.1 & 650.5 & 169.7 & 107.6 & 248.1 & 125.0 & 1944.6 & 1195.2 & 346.1 & 200.2 \\
\hline Metribuzin & 21.3 & 10.3 & 168.7 & 104.0 & 23.6 & 14.4 & 45.3 & 20.0 & 416.1 & 243.9 & 56.5 & 30.0 \\
\hline $\begin{array}{c}\text { Tribenuron- } \\
\text { methyl }\end{array}$ & 160.4 & 90.4 & 1223.8 & 810.8 & 207.0 & 129.4 & 313.0 & 159.0 & 2410.1 & 1468.8 & 406.3 & 235.0 \\
\hline Metosulam & 145.0 & 84.9 & 1113.5 & 48.0 & 187.2 & 121.9 & 281.0 & 150.7 & 2261.0 & 1369.6 & 382.5 & 226 \\
\hline Bentazon & 113.9 & 71.9 & 854.3 & 598.3 & 152.2 & 99.7 & 237.0 & 119.0 & 1823.1 & 1010.1 & 329.7 & 170.2 \\
\hline Oxadiargyl & 43.4 & 20.0 & 345.3 & \begin{tabular}{|l|}
190.7 \\
\end{tabular} & 56.4 & 29.3 & 121.3 & 21.4 & 870.5 & 408.7 & \begin{tabular}{|l|}
144.8 \\
\end{tabular} & 67.0 \\
\hline $\begin{array}{c}\text { Two hand } \\
\text { hoeing }\end{array}$ & 14. & 6.3 & 10 & 73 & 4.6 & 9.4 & 36 & .7 & 1 & 2 & .1 & 19.6 \\
\hline Unweeded & 473.3 & 230.0 & 3681.4 & 2388.5 & 628.0 & 396.4 & 852.1 & 443.1 & 6653.2 & 4421.7 & 1074.0 & 706.2 \\
\hline LSD at 0.05 & 4.5 & 1.7 & 12.3 & 32.4 & 6.5 & 3.3 & 4.1 & 2.7 & 15.8 & 39.6 & 11.4 & 5.7 \\
\hline
\end{tabular}

\section{2- Maize plants:-}

A - Growth of maize plants characters:-

Weed control treatments significantly increased growth characters i.e. plant height, fresh and dry weight of shoot and leaves / plant at 60 and 80 DFS in the two seasons (Tables 5 and 6 ). Two hand hoeing treatment recorded the highest values of the growth characters followed by Metribuzin, Fluroxypyr, Oxadiargyl and Bentazon. While, number of leaves / plant was not significantly affected by different weed control treatments at 60 and 80 DFS in both 2006 and 2007 seasons.

Table 5: Average of plant height, fresh and dry weight of shoot / maize plant after 60 and 80 DFS as affected by weed control treatments of 2006 and 2007 growing seasons

\begin{tabular}{|c|c|c|c|c|c|c|c|c|c|c|c|c|}
\hline \multirow{3}{*}{ Characters } & \multicolumn{4}{|c|}{ plant height $(\mathrm{cm})$} & \multicolumn{4}{|c|}{$\begin{array}{c}\text { Fresh weight of shoot / } \\
\text { plant (gm) }\end{array}$} & \multicolumn{4}{|c|}{$\begin{array}{c}\text { Dry weight of shoot / } \\
\text { plant (gm) }\end{array}$} \\
\hline & \multicolumn{2}{|c|}{$\begin{array}{l}\text { after } 60 \\
\text { days }\end{array}$} & \multicolumn{2}{|c|}{ after 80 days } & \multicolumn{2}{|c|}{$\begin{array}{c}\text { after } 60 \\
\text { days }\end{array}$} & \multicolumn{2}{|c|}{ after 80 days } & \multicolumn{2}{|c|}{$\begin{array}{l}\text { after } 60 \\
\text { days }\end{array}$} & \multicolumn{2}{|c|}{$\begin{array}{c}\text { after } 80 \\
\text { days }\end{array}$} \\
\hline & 2006 & 2007 & 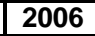 & 2007 & 2006 & 2007 & & & 2006 & 2007 & 2006 & 2007 \\
\hline Fluroxypyr & 293.3 & & & & & & & & & & & \\
\hline & & & & & & & & & & & & \\
\hline & & & & & & & & & & & & \\
\hline methyl & 260.4 & 271.8 & & 3 & 7 & 7 & & 1056.2 & & 148.9 & 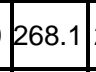 & 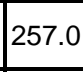 \\
\hline Metosulam & 4.0 & & & & & 6 & & & & 156.0 & .1 & 246.5 \\
\hline azon & 289.4 & 3 & & & 6 & 675.7 & & & & .0 & 6 & 295.5 \\
\hline iargyl & 291.3 & 293.5 & & 310.0 & 676.7 & 677.0 & 1205.0 & & & 168.0 & 293.0 & 303.8 \\
\hline $\begin{array}{l}\text { Two hand } \\
\text { hoeing }\end{array}$ & 303.8 & 05.0 & $3<2.2$ & 322.7 & 6 & P & 10.1 & 14 & & 18 & 1 & 1 \\
\hline & 57.2 & & & 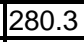 & & & & & & & & \\
\hline a & 13. & & TL & & 5 & 4. & & & & 3.8 & .1 & \\
\hline
\end{tabular}


Ahmed, S. A. et al.

Table 6: Average of fresh and dry weight of leaves and No. of leaves / maize plant after 60 and 80 DFS as affected by weed control treatments of 2006 and 2007 growing seasons.

\begin{tabular}{|c|c|c|c|c|c|c|c|c|c|c|c|c|}
\hline \multirow{3}{*}{ Characters } & \multicolumn{4}{|c|}{$\begin{array}{l}\text { Fresh weight of leaves / } \\
\text { plant (gm) }\end{array}$} & \multicolumn{4}{|c|}{$\begin{array}{c}\text { Dry weight of leaves / } \\
\text { Plant (gm) }\end{array}$} & \multicolumn{4}{|c|}{ No. of leaves / Plant } \\
\hline & \multicolumn{2}{|c|}{ after 60 days } & \multicolumn{2}{|c|}{ after 80 days } & \multicolumn{2}{|c|}{ after 60 days } & \multicolumn{2}{|c|}{ after 80 days } & \multicolumn{2}{|c|}{ after 60 days } & \multicolumn{2}{|c|}{$\begin{array}{c}\text { after } 80 \\
\text { days }\end{array}$} \\
\hline & 2006 & 007 & 2006 & $t$ & 2006 & 77 & 6 & $\overline{007}$ & 2006 & 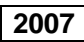 & 2006 & \\
\hline Fluroxypyr & & & & & & & & & & & & \\
\hline & & & & & & & & & & & & \\
\hline in & 1 & & & & & & & & & & & \\
\hline $\begin{array}{l}\text { uron } \\
\text { hyl }\end{array}$ & 11 & 1.0 & b1 & 235. & 29. & 5 & 51 & 54.7 & 10 & 11.5 & 11.1 & 14 \\
\hline $\mathrm{am}$ & & & & & & & & & & & & \\
\hline & 5 & & & & 32 & & 53. & 6.0 & & & & \\
\hline iargyl & 5 & $\underline{5}$ & 25 & & - & & 60.0 & 8.0 & & & & $\overline{15.3}$ \\
\hline \begin{tabular}{|c|}
$\begin{array}{c}\text { Two hand } \\
\text { hoeing }\end{array}$ \\
\end{tabular} & a & 4 & 0 & 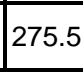 & 4 & 47.1 & 62.6 & 64.1 & 12.7 & 12.6 & 14.6 & 15.4 \\
\hline ded & \begin{tabular}{|l|l|}
124.4 \\
\end{tabular} & & 200.0 & & 26.9 & & 46.5 & 47.4 & & & & \begin{tabular}{|l|}
14.0 \\
\end{tabular} \\
\hline LSDat 0.05 & 11.3 & 5.2 & 13.6 & 5.3 & 4.1 & 5.0 & 4.5 & 5.1 & N.S & N.S & N.S & N.S \\
\hline
\end{tabular}

N.S = Non significant

Generally, it can be concluded that growth characters of maize plants affected by the density of weeds $/ \mathrm{m}^{2}$. The growth characters of the second season higher than the growth characters of the first season which as a result of density of weeds in the first season higher than the density of weeds in the second season. From the recorded results it can be revealed that the highest increment in growth characters of maize plants were achieved from plots treated with two hand hoeing, Metribuzin, Fluroxypyr, Oxadiargyl and Bentazon treatments. These treatments minimized the weed competition with maize plants (Tables 5 and 6 ) and consequently increased the capacity of maize plants in utilizing the environmental factors i.e. light, nutrients and water in building great amount of metabolites available for building new tissues and this might account for the previous findings. Similar results were mentioned by Singh and Singh (2003), Kobeasy et al. (2005), Sharara et al. (2005) and El - Metwally et al. (2006).

\section{B- Yield and its attributes:}

B-1- Weight of ears / plant (gm):

Results in Table 7 revealed that controlling weeds significantly increased weight of ears / plant in both seasons. Metribuzin, two hand hoeing, Fluroxypyr, Oxadiargyl and Bentazon produced the highest values of ear weight / plant in both seasons.

\section{B-2- Ear length (cm):}

It is evident that ear length significantly increased by weed control treatments in 2006 season (Table 7). Application of two hand hoeing followed by Metribuzin, Fluroxypyr, Bentazon and Oxadiargyl increased ear length as compared with the other treatments. The lowest ear length was recorded from unweeded treatment. Results also, cleared that ear length was not significantly affected by different weed control treatments in 2007 season.

\section{B-3- Ear Diameter and number of rows / ear:}

Results in Table 7 indicated that ear diameter and number of rows / 
ear were not significantly affected by different weed control treatments in 2006 and 2007 seasons.

\section{B-4 - Number of kernels / row:}

Two hand hoeing and the herbicidal treatments markedly produced higher number of kernels / row than unweeded plots (Table 7). In both seasons, the highest increase in number of kernels / row was obtained by two hand hoeing treatment followed by Metribuzin, Fluroxypyr, Oxadiargyl and Bentazon. The increases amounted to $44.1,40.8,37.3,35.7$ and $34.3 \%$ in the first season and 12.0, 5.9, 5.5, 4.4 and $4.4 \%$ in the second season over unweeded treatment, respectively.

It can be concluded that yield and its attributes affected by the density of weeds. By increasing the density of weeds $/ \mathrm{m}^{2}$ as found in the first season, yield and its attributes were decreased. While, in the second season by decreasing the density of weeds $/ \mathrm{m}^{2}$ yield and its attributes were increased.

The reported results indicate that the highest increases in yield attributes of maize plants were achieved from plots treated with two hand hoeing, Metribuzin, Fluroxypyr, Oxadiargyl and Bentazon treatments. The superiority of these treatments in this respect contributed in controlling maize weeds and consequently improved yield attributes of maize. These results are in general agreement with those obtained by El - Metwally et al. (2001), Mekky (2001), El - Metwally (2002), Sharara et al. (2005) and El - Metwally et al. (2006).

Table 7: Averages of Yield and yield attributes of maize plants as affected by weed control treatments of 2006 and 2007 growing seasons.

\begin{tabular}{|c|c|c|c|c|c|c|c|c|c|c|c|}
\hline \multirow{3}{*}{$\begin{array}{l}\text { Characters } \\
\text { Treatments }\end{array}$} & \multicolumn{10}{|c|}{ Ear characters } & \multirow[b]{2}{*}{$\begin{array}{l}\text { Grain Yield } \\
\text { *(ardab / } \\
\text { fed.) }\end{array}$} \\
\hline & \multirow{2}{*}{\multicolumn{2}{|c|}{\begin{tabular}{|c|}
$\begin{array}{c}\text { Weight of } \\
\text { ears / plant } \\
\text { (gm) }\end{array}$ \\
2006 (2007
\end{tabular}}} & \multicolumn{2}{|c|}{$\begin{array}{c}\text { Ear length } \\
\text { (cm) }\end{array}$} & \multicolumn{2}{|c|}{$\begin{array}{c}\text { Ear } \\
\text { diameter } \\
(\mathbf{c m})\end{array}$} & \multicolumn{2}{|c|}{$\begin{array}{c}\text { No. of } \\
\text { rows/ ear }\end{array}$} & \multicolumn{2}{|c|}{$\begin{array}{c}\text { No. of } \\
\text { kernels/ } \\
\text { row }\end{array}$} & \\
\hline & & & 2006 & 2007 & 2006 & 2007 & 2006 & 2007 & 2006 & 2007 & \begin{tabular}{|l|l|}
2006 & 2007
\end{tabular} \\
\hline Furo & 242.6 & 282 & 20.10 & 21.11 & 4.50 & 4.84 & 13.2 & .1 & 50.8 & 48.2 & 27.50 \\
\hline ron & 227.4 & 245.3 & 19.40 & 20.20 & 4.40 & 4.71 & 12.4 & 13.5 & 49.4 & 47.3 & \begin{tabular}{|l|l|}
22.16 .10 \\
\end{tabular} \\
\hline letribuzin & 272.3 & 303.0 & 20.94 & 21.83 & 4.6 & 4.78 & 13.2 & & 52.1 & 48.4 & 80 \\
\hline $\begin{array}{l}\text { Tribenuron- } \\
\text { methyl }\end{array}$ & 205.7 & $\mid<<<.4$ & 15.11 & 20.45 & 4.28 & 4.70 & 12.1 & 13.5 & 46.7 & 47.2 & 45 \\
\hline Metosulam & 211.2 & 234.7 & 19.25 & 20.23 & 4.32 & 4.75 & 12.4 & 13.5 & 47. & 46.4 & \begin{tabular}{|l|l|}
20.16 & 20.4 \\
\end{tabular} \\
\hline Bentazon & 231.9 & 273.5 & 9.77 & 20.65 & 4.42 & 4.76 & 12.6 & 13.6 & 49.7 & 47.7 & \begin{tabular}{|l|l|}
26.40 .12 \\
\end{tabular} \\
\hline Oxadiargyl & 235.7 & 279.0 & 19.59 & 20.91 & \begin{tabular}{|l|}
4.48 \\
\end{tabular} & 4.78 & \begin{tabular}{|l|}
12.8 \\
\end{tabular} & 13.8 & 50.2 & 47.7 & \begin{tabular}{|l|l|}
26.70 .82 \\
\end{tabular} \\
\hline $\begin{array}{l}\text { Two hand } \\
\text { hoeing }\end{array}$ & 2554 & 207 & 2125 & .86 & 4.62 & 4.86 & 13.6 & 14.3 & 53.3 & 512 & 0 \\
\hline Unweeded & 179.5 & 205.5 & 6.80 & 0.02 & 4.25 & 4.65 & 12.0 & 13.4 & 37.0 & $\pi$ & \begin{tabular}{|l|l|}
15.16 & 15 \\
\end{tabular} \\
\hline 0.05 & 16.1 & 7.6 & 2.08 & N.S & N.S & N.S & N.S & N.S & 4.5 & 3.2 & \begin{tabular}{l|l}
1.33 & 0.71 \\
\end{tabular} \\
\hline
\end{tabular}

\section{B -5- Grain yield:}

Grain yield in ardab / fed was significantly affected by different weed control treatments in 2006 and 2007 seasons as showed in Table 7. Two 
hand hoeing and all herbicidal studied treatments significantly produced higher grain yield than the unweeded plots. The highest increment in grain yield was obtained with two hand hoeing followed by Metribuzin, Fluroxypyr, Oxadiargyl and Bentazon. The increases amounted to 91.3, 86.0, 81.4, 76.1 and $74.1 \%$ in 2006 season, respectively and 97.8, 93.5, 81.7, 80.4 and $75.9 \%$ in the second season over the unweeded treatment, respectively.

On the other side, the lowest increase in grain yield over the unweeded plant was recorded with Tribenuron - methyl treatment. The superiority of the previous treatments in producing high grain yield might be due to increased the reduction in number, fresh and dry weight of weeds grown with maize plants Tables 2, 3 and 4 and minimized the weed competition with maize plants and consequently increased the capacity of maize plants in utilizing the environmental factors i.e. light, nutrients and water in building great amount of metabolites available for building new tissues and this might account for the previous findings. This reflected on increasing growth, yield attributes of maize (weight of ears / plant, ear length and number of kernels / row) resulted in increasing in grain yield / unit area. These results are in good accordance with those obtained by Abd EI - Samie (2001), El - Metwally et al. (2001), Mekky (2001), El - Metwally (2002), Saad El - Din et al. (2004), Kobeasy et al. (2005), El - Metwally et al. (2006) and Abouziena et al. (2007).

\section{C-Chemical composition of maize grains: \\ C.1 Protein percentage:}

Results in Table 8 indicated that protein percentage in maize grains was significantly increased by weed control treatments as compared to unweeded check. The highest protein percentage was recorded with hoeing treatment (9.89 and 10.01\%), followed by Metribuzin (9.86 and $9.94 \%$ ), Fluroxypyr (9.70 and 9.84\%), Bentazon (9.62 and 9.78\%) and Oxadiargyl $(9.60$ and $9.66 \%)$ in both seasons, successively. These superior treatments increased the average of protein percentage than the unweeded treatment by about $14.60,14.25,12.40,11.47$ and $11.24 \%$, respectively in the first season and increased by about 14.66, 13.86, 12.71, 12.03 and $10.65 \%$, successively in the second season. While, the lowest increase in protein \% over unweeded treatment was recorded with Isoproturon treatment. Similar results were confirmed by Kobeasy et al. (2005), Sharara et al. (2005), El Metwally et al. (2006) and Abouziena et al. (2007).

\section{C-2 Oil percentage:}

Results indicated that all studied weed control treatments increased markedly the oil percentage than the unweeded treatment as shown in Table 8. The highest increase in oil \% was obtained by Metribuzin treatment followed by that of Fluroxypyr, Oxadiargyl, two hand hoeing and Bentazon treatments, respectively. These superior treatments increased the average of oil percentage than the unweeded treatment by about 20.6, 19.9, 11.3, 9.8 and $8.5 \%$, respectively in 2006 season and increased by $20.7,19.9,10.6,9.9$ and $9.6 \%$, consequently in 2007 season. On the contrary, the lowest increase in oil \% over the unweeded treatment was recorded with Metosulam treatment. These findings are supported by El - Metwally et al. (2001), El Metwally (2002), Kobeasy et al. (2005) and El - Metwally et al. (2006). 
Table 8: Chemical composition of maize grains as affected by weed control treatments in both seasons 2006 and 2007 seasons.

\begin{tabular}{|c|c|c|c|c|c|c|}
\hline Characters & \multicolumn{2}{|c|}{ Protein \% } & \multicolumn{2}{c|}{ Oil \% } & \multicolumn{2}{c|}{ Carbohydrates \% } \\
\cline { 2 - 7 } Treatments & $\mathbf{2 0 0 6}$ & $\mathbf{2 0 0 7}$ & $\mathbf{2 0 0 6}$ & $\mathbf{2 0 0 7}$ & $\mathbf{2 0 0 6}$ & $\mathbf{2 0 0 7}$ \\
\hline Fluroxypyr & 9.70 & 9.84 & 4.77 & 4.87 & 75.40 & 78.55 \\
\hline Isoproturon & 9.06 & 9.18 & 4.31 & 4.39 & 73.0 & 47.10 \\
\hline Metribuzin & 9.86 & 9.94 & 4.80 & 4.90 & 78.40 & 79.30 \\
\hline Tribenuron - methy & 9.37 & 9.43 & 4.22 & 4.26 & 75.00 & 75.24 \\
\hline Metosulam & 9.26 & 9.32 & 4.11 & 4.17 & 73.26 & 74.10 \\
\hline Bentazon & 9.62 & 9.78 & 4.32 & 4.45 & 75.26 & 76.36 \\
\hline Oxadiargyl & 9.60 & 9.66 & 4.43 & 4.49 & 75.35 & 76.50 \\
\hline Two hand hoeing & 9.89 & 10.01 & 4.37 & 4.46 & 79.98 & 80.94 \\
\hline Unweeded & 8.63 & 8.73 & 3.98 & 4.06 & 70.70 & 72.84 \\
\hline LSD at 0.05 & 0.15 & 0.18 & 0.09 & 0.11 & 1.05 & 1.10 \\
\hline
\end{tabular}

\section{C-3 Carbohydrate percentage:}

Results in Table 8 indicated that controlling weeds by hand hoeing and chemical treatments caused significant increases in percent of carbohydrates over the unweeded check. The highest carbohydrates percent was observed from two hand hoeing followed by Metribuzin, Fluroxypyr, Oxadiargyl and Bentazon. The superior treatments increased carbohydrates percent than unweeded treatment by about 13.1, 10.9, 6.7, 6.6 and $6.5 \%$, respectively in the first season and increases by about 11.1, 8.9, 7.8, 5.0 and $4.8 \%$, successively in the second season. While the least carbohydrate percent was recorded from unweeded check. Our results are in agreement with those obtained by Elgayar (2004), Mohamed (2004) and El - Metwally et al. (2006).

It can be observed that protein, oil and carbohydrate percentages in 2007 season were higher than 2006 season, this related to the higher density of weeds $/ \mathrm{m}^{2}$ in the first season than the second season.

Therefore, we could concluded that the application of two hand hoeing and herbicides treatments decreased significantly number, fresh and dry weight of broad leaved, grass and total weeds. Such results cleared that two hand hoeing and herbicidal treatments were efficient in increasing productivity of maize and the highest grain yield of maize by two hand hoeing or choosing the most suitable herbicides (Metribuzin, Fluroxypyr, Oxadiargyl and Bentazon).

\section{REFERENCES}

Abd El - Samie, F. S. (2000). Efficiency of Metribuzin application methods in five maize varieties. Proc. $9^{\text {th }}$. Conf., Agron., Minufiya Univ., 1- 2 Sept.: 211- 222.

Abd El - Samie, F. S. (2001). Effect of plant population density and weed control on growth and yield of maize crop and it's associated weeds. Minufiya J. Agric. Res., 26(1): 85 - 98.

Abouziena, H. F.; M. F. El - Karamany, M. Singh and S. D. Sharma (2007). Effect of nitrogen rate and weed control treatments on maize yield and associated weeds in sandy soils. Weed Tech., 21: $1049-1053$. 
Ahmed, S. A. (1999). Effect of plant population and some weed control treatments on maize and it's associated weeds J. Agric. Sci. Mansoura Univ., 24 (10): 5605 - 5625.

A. O. A. C. (1980). Association of Official Agriculture Chemists $\square \square$ "Official methods of analysis" $13^{\text {th }}$ Ed. Washington, Dc, USA.

Attalla, S. I. (2002a). Effect of weed control treatments and two sowing methods on weeds and sorghum [Sorghum bicolor (L.)]. Bull. Fac. Agric., Cairo Univ., 53: 539 - 552.

Attalla, S. I. (2002b). Effect of weed control treatments and $\mathrm{N}-$ fertilizer rates on weeds and sorghum. Bull. Fac. Agric., Cairo Univ., 53: 365 - 376.

Chapman, H. D. and P. F. Pratt (1978). Methods for analysis for soil , plants an water. University of California, Department of Agricultural Science, USA: $1-309$.

Elgayar, S. H. (2004). Effect of some weed control treatments and foliar fertilization on growth, yield and it's attributes, chemical composition and it's associated weeds of maize plants at Nobarya. J. Agric. Sci. Mansoura Univ., 29 (7): 3993 - 4003.

El - Metwally, I. M. (2002). Efficacy of adding urea on some herbicides efficiency in controlling weeds associated in maize crop. Zagazig. J. Agric. Res., 29 (4): 1093 - 1112.

El - Metwally, I . M.; M. R. Abd El Razik and M. M. Zain El Din (2006). Effect of some weed control treatments on growth, yield, yield attributes, some seed technological characters of maize plants and it's associated weeds J. Agric. Sci. Mansoura Univ., 31 (7) : 4259 - 4270.

El - Metwally, I. M.; S. A. Ahmed and S. A. Saad El - Din (2001). Nitrogen fertilizer levels and some weed control treatments effects on maize and it's associated weeds. J. Agric. Sci. Mansoura Univ., 26 (2): $585-601$.

Gomez, K.A. and A.A.Gomez(1984). Statistical procedures for Agric. Res. John Wiley and Sons. Inc., New York,U.S.A.

Herbert, D.; P. J. Phipps and R.E. strange (1971).Determination of total carbohydrate. Methods in methodology, 5B: $209-344$.

Kobeasy, M. I.; R. O. Osman; E. R. El Desoki and S. R. El - Lethy (2005). Effect of Basagrane and Strane herbicides on chemical composition and crop characters of sorghum grains. J. Agric. Sci. Mansoura Univ., 30 (3): $1755-1771$

Konstantinovic, B. and M. Meseldzija (2007). More recent possibilities of corrective weed control in maize, sunflower and soybean. Herbologia, $8(1): 57-65$.

Mekky, M.S. (2001). Control of broadleaf weeds in maize (Zea mays L). Minia. J. of Agric. Res \& Develop., 21 (3): 387 - 399.

Mohamed, S. A. (2004). Efficiency of using abscisic acid and some weed control treatments in controlling associated weeds growth, yield and chemical composition of maize plant. Egypt J. Appl. Sci., 19 (9B): 452 465.

Saad EI - Din, S. A. and S. A. Ahmed (2004). Impact of seedling rate and some weed control treatments on wheat and its associated weeds. Egypt J. Appl. Sci., 19 (4). $59-83$.

Saad El - Din, S. A.; N. K. Messiha and G. M. Metwely (2004). Response of maize and associated weeds to some post - emergence herbicides. J. Agric. Sci. Mansoura Univ., 29 (3): 1227 - 1237. 
Senseovic, T. (2004). Preparation for protecting maize from pests and weeds. Glasnik Zastite Bilja, 27(3): 5 - 34.

Sharara, F. A. A.; T. A. El Shahawy and K. G. El Rokiek (2005). Effect of some novel herbicides on controlling weeds associated with maize plants. J. of Agron., 4 (2): 88 - 95.

Sharma, A. R.; A. S. Toor and H. S. Sur (2000). Effect of inter culture operations and scheduling of atrazine application on weed control and productivity of rainfed maize (Zea mays) in Shiwalik foothills of Punjab. Ind. J. of Agric. Sci., 70 (11): $757-761$.

Singh, A. P. and P. C. Singh (2003). Effect of different weed control methods on growth and yield of rabi sown hybrid maize cv. Hybrid 4640. J. of Living World, 10(2):12 - 15.

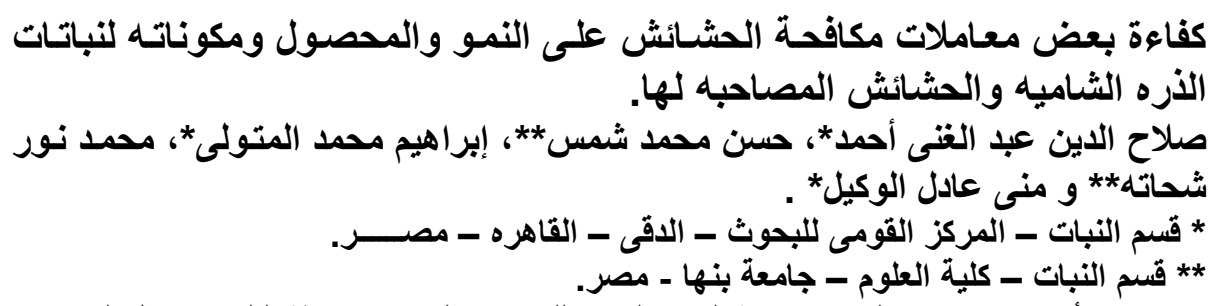

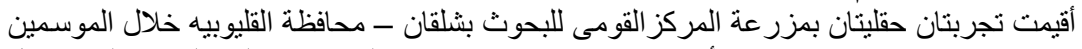

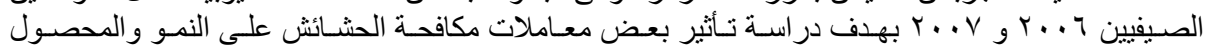

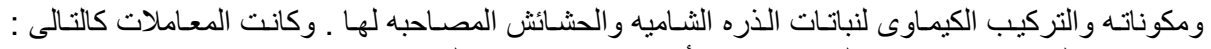

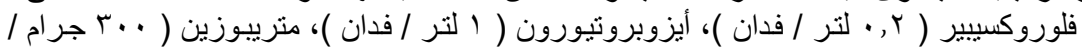

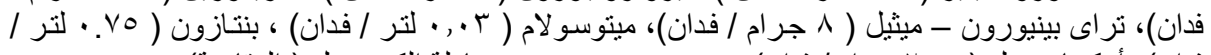

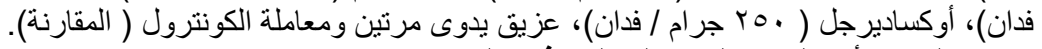

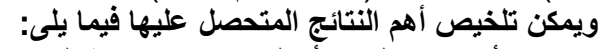

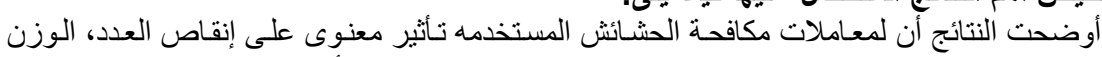

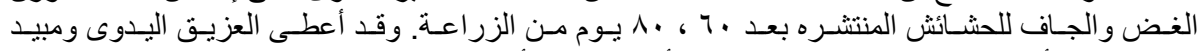

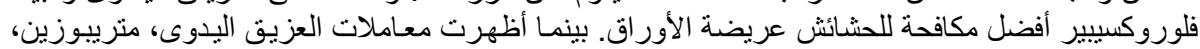

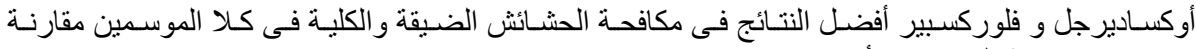

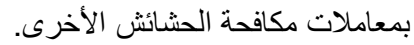

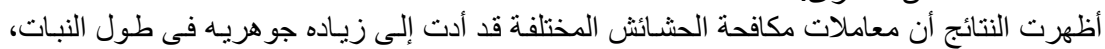

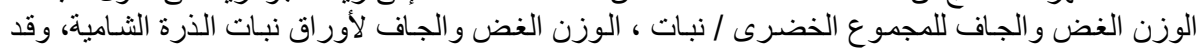

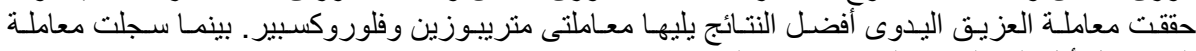
الكونترول أقل القيم لجميع الصفات تحت الدان الداسية.

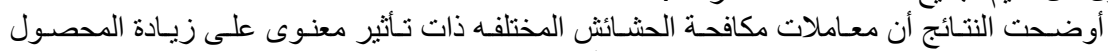

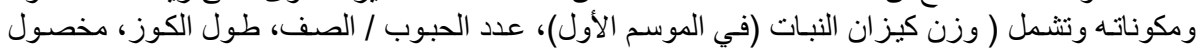

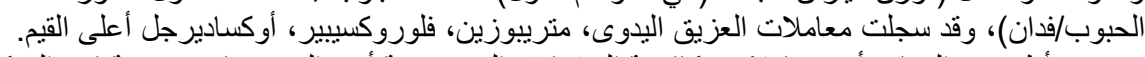

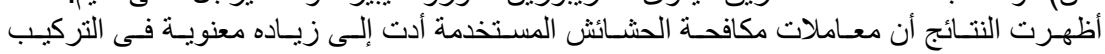

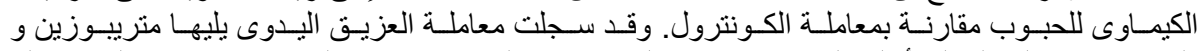

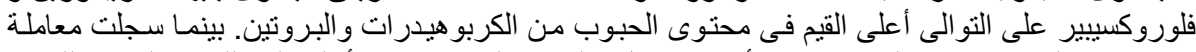

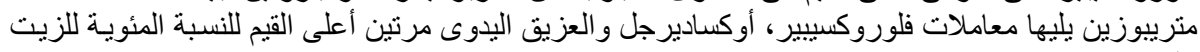

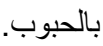

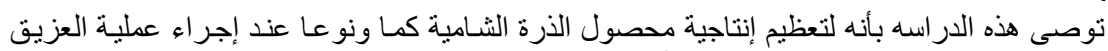

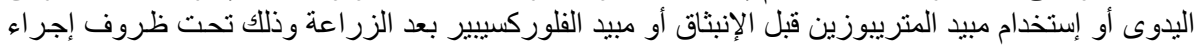

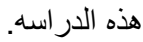

